\title{
Inconsistent Constitutional Court Decisions Resulting in Uncertainty in Legal Dispute Regarding Regional Head Election Results
}

\author{
Saut Parulian Manurung \\ Universitas Kristen Darma Cendika, Indonesia \\ saudjoee@gmail.com
}

\begin{abstract}
In Indonesia, the Constitutional Court is the sole interpreter and guardian of the constitution, and the decision made by such a Court is expected to meet a sense of justice, utility, and legal certainty. This paper argues that there is a contradiction between decisions ruled by the Court resulted in the inconsistency against constitutional interpretations. Such inconsistency can refer to the decision of the Constitutional Court No. 072-073 / PUU-II/2004 declaring the Constitutional Court to have the power to decide disputes over the results of regional head elections. On the other hand, Decision No. 97/PUU$\mathrm{XI} / 2013$ ruled this institution no longer to adjudicate disputes over the results of regional elections so that it revokes Article 236C of the revised Regional Government Act No. 12/2008. In doing so, this paper analyzes the impact of such contradictory decisions and how both decisions have effects on legal certainty over disputes of the regional head election. This paper concludes that the application of two different approaches caused such inconsistency: the first decision applied judicial activism and the latter considered judicial restraint.
\end{abstract}

KEYWORDS: Inconsistency, Constitutional Interpretation, Judicial Restraint, Judicial Activism.

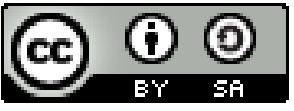

Copyright $\odot 2019$ by Author(s)

This work is licensed under a Creative Commons Attribution-ShareAlike 4.0 International License. All writings published in this journal are personal views of the authors and do not represent the views of this journal and the author's affiliated institutions.

\section{HOW TO CITE:}

Manurung, Saut Parulian. "Inconsistent Constitutional Court Decision Resulting in Uncertainty Regarding the Legal Dispute on Regional Head Election Result in Indonesia" (2019) 6:2 Lentera Hukum 32l-336.

Submitted: May 28, 2019 Revised: June 15, 2019 Accepted: July 30, 2019 


\section{INTRODUCTION}

The Indonesian Constitutional Court is a judicial institution established through the third amendment of the 1945 Constitution with the idea to introduce judicial review. ${ }^{1}$ One of the powers granted to the Constitutional Court is constitutional review of laws against the 1945 Constitution and other powers outlined in the 1945 Constitution, among other things, the dissolution of political parties, constitutionality of state institution's power, the settlement of electoral results, and impeachment. Amongst such powers, the Constitutional Court has the underlying functions, viz. the guardian and the final interpreter of the constitution, which includes the protector of human rights, citizens, and democracy. ${ }^{2}$

This paper will examine the Constitutional Court in interpreting the constitution and whether the interpretation is consistent in decisions to meet legal certainty. There is a contradiction between two decisions ruled by the Court resulted in inconsistent constitutional interpretations. Such inconsistency refers to the decisions of the Constitutional Court No. 072-073/PUU-II/2004 and No. 072-073/PUU-II/2004 ${ }^{3}$ declared the Constitutional Court to have the power to adjudicate disputes over the results of regional head elections. The Constitutional Court considered Article 18 (4) of the 1945 Constitution is classified into Article 22C of the 1945 Constitution so that regional head elections are grouped into general elections. As a result, the power to examine, hear, and decide on disputes over general elections and regional head elections has belonged to the Constitutional Court. ${ }^{4}$ The new Act No. 12/2008 revising Act No. 32/2004 on Regional Governments, then emphasized that the settlement over regional head election disputes head must be transferred to the Constitutional Court under Article 236 C of Act No. 12/2008.

On the other hand, the decision No. 97/PUU-XI/2013 ruled this institution no longer to decide disputes over the results of regional head elections by revoking Article 236C of the revised Regional Government Act No. 12/2008. After Decision No. 97/PUU$\mathrm{XI} / 2013$, the Constitutional Court reversed its power to settle on disputes over the results of regional head elections, by deciding Article 236C of Act No. 12/2008 on Regional Governments contradicts the 1945 Constitution and does no longer have legal binding. In the second point of the decision, the Constitutional Court has retained such a power to settle disputes over regional head elections as long as no regulations govern it. ${ }^{6}$ Differences decision on reviewing the two regulations with the same substance in a different time may have implications on the aspect of legal certainty. This article will

Secretariat General and Registrar of the Constitutional Court, Constitutional Court Procedure Law, (Jakarta: Secretariat General and Registrar of the Constitutional Court, 2010) at 5.

2 Ibid at 10.

3 While 2004 was the similar case. These case were petitioned by the Center for Election Reform Center, Muhamad Taufik, et al.

4 Constitutional Court of the Republic of Indonesia, Decision No. 072-073/PUU-II/2004 at 106.

5 Decision of the Constitutional Court No. 97/PUU-XI/2013, judicial review of Law No. 12 of 2008 on the second Amendment to Law No. 32 of 2004 concerning Regional Government of the 1945 Constitution, which was petitioned by applicants Victor Santoso Tandiasa, Ryan Muhammad, Okta Heriawan, et al.

6 Constitutional Court of the Republic of Indonesia, supra note 4. 
focus on the analysis of the legal impact of the inconsistency of the Constitutional Court through the decisions No. 072-073/PUU-II/2004 and No. 97/PUU-XI/2013, which cast doubt on the certainty law.

Previous research related to this topic was conducted by Sigit Setiawan. Sigit's study discussed legal considerations used by judges of the Constitutional Court on deciding related cases, differences in interpretation methods used by judges, and the suitability of legal considerations of the Constitutional Court based on positive law and legal principles. ${ }^{7}$ That study differs from my research because this research analyzes a new dimension, that is a paradigm shift of the judge in deciding in the dispute over the election of regional head and deputy regional head. This analysis precipitates a difference in the verdict against the testing of different regulations but with the same substance. The paradigm shift between referred to in the study of this article is between the paradigm of judicial activism and judicial restraint. Such a paradigm can be interpreted as a judge and court approach in controlling or influencing the institutions or that are authorized to make decisions and policies and balanced with the existence of a policy on their authority. Thus, they can refrain in making or deciding a policy that is not the realm of professionalism.

\section{THE NATURE OF “DEMOCRATICALLY ELECTED” REGIONAL HEAD ELECTION}

Before reviewing the implications of the inconsistency of the Decision Constitutional Court in the context of regional head elections disputes, it is necessary to analyze the nature of the phrase "democratically elected" in Article 18 paragraph (4) of the 1945 Constitution. Comprehensive Guide of the 1945 Constitutional amendment provides an understanding of the intentions of the initial (original intent) of the framers of the constitution amendment NRI 1945.

One of the discussions conducted during the third amendment to the 1945 constitutional amendment was related to the election of members of the Regional Representative Council (DPD). The material associated with this stage contains in the MPR Decree No. XI/MPR/2000 on March 29, 2001. The meeting scheduled hearings the existence of a joint discussion with the expert team conducted by Ismail Suny and the meeting was chaired by Jakob Tobing (an expert in the political field).

Nazaruddin Sjamsuddin, the team in the discussion, stated that the expert team did not agree with the formulation of the People's Consultative Assembly's Work Council for Article 2 paragraph (1). Nazaruddin revealed as follows ${ }^{8}$ :

Then concerning Chapter II Article 2, the formulation made by the Workers'

Agency if we read the response from the team letterly in writing does not agree,

Sigit Setiawan, Inconsistency of the Constitutional Court Decision Regarding the Authority to Trial Dispute over Regional Head Election, Thesis, Muhammadiyah Law Faculty of Surakarta, 2016 at 2.

8 Comprehensive Manuscript of Amendment to the 1945 Constitution of the Republic of Indonesia, Book V of General Elections, (Jakarta: Secretariat General and Registrar's Office of the Constitutional Court, 2010) at 121. 
replace with a new one. So, indeed, that was rejected. Although there are ideas that we agree on so that our proposal is as follows, the People's Consultative Assembly consists of members of the Regional Representative and members of the Regional Representative Council elected through general elections.

I want to underline the term chosen through general elections, and this means that no more members are appointed directly by an institution but must be chosen through general elections conducted jointly-together. The regarding point 2 or paragraph (2) there, it also cannot be accepted by the political team. I formulate the People's Consultative Assembly Session was a joint meeting between the DPR and DPD which took place at least once in five years in the national capital.

Based on the views expressed by Nazaruddin in Proceedings of Manuscripts Comprehensive Amendment to the 1945 Constitution, there were an interpretation over the meaning of the election of members of the House of Representative or Regional Representative Council must be carried out through general elections, not through appointment of members can result in violation of the existing democratic process. Therefore, "democratic" in member elections is interpreted as the antithesis of the mechanism of appointment for political office.

Comprehensive Manuscript for Amendment to the 1945 Constitution (Book V on Elections) explains some opinions of the expert team on what is meant by democratic elections. At the time the $14^{\text {th }}$ MPR BP PAH I meeting was held on May 10, 2001, with the agenda of reading the opinions of the expert team regarding the formulation of general elections. Speaker Lukman Hakim Saifuddin from F-PPP argued for Article 18 of the Constitution Republic of Indonesia by saying as follows: ${ }^{9}$

As for the Regional Head, in my opinion, we are consistent only in Article 18 that have been agreed on the second amendment that local elections were conducted democratically further regulated by regulation. So whether the law would control directly or as applicable today by Parliament let the laws that govern.

Baharuddin at the time also gave a message to remind all members who participated in the amendment discussion, not hastily exclude the words of the Regional Head in the formulation of paragraph (2) of the expert team. As for those delivered as follows: ${ }^{10}$

Then I just reminded again to Chapter VII that we agreed about the head of this region put aside. And for paragraph (2) of the expert team is the most suitable, but the argument indeed when we arrange Article No. 18, the regional head was democratically elected. It also includes if, for example, the election carried out directly by the people. I remember that time, and we will arrange it later in regulation. The reason was that in our opinion, to strengthen it again.

Explicitly, the expert team's opinion on Article 18 paragraph (4) to the 1945 Constitution shows two very fundamental conclusion options. First, that regional head elections in a democratic manner means that a candidate for regional head is elected through their respective regional regulatory mechanisms by respecting sovereignty or regional autonomy which is submitted to the DPRD. Second, the meaning of

$9 \quad$ Ibid at 578 .

10 Ibid at 585 . 
"democratically" in addition to the role of the DPRD to ensure regional election rules can be given the meaning that "democratically" is also the scope of direct elections. This is because voters are faced directly to leaders who represent their voices with the recruitment process.

In understanding the phrase "democratically," we can also refer to the essential elements which are consequences of "democracy." The fundamental factors, according to Afan Gaffar, are as follows: (1) People enjoy what become of their fundamental rights including the right to associate, assemble (freedom of assembly), the right to argue (freedom of speech), and enjoyed a free press freedom of press); (2) There are general elections held regularly, and voters are free to make their choices without any elements of coercion; (3) As a consequence, people can actualize themselves maximally in political life by carrying out independent political participation (autonomous participation) without being mobilized; (4) The possibility of ruling rotation as a product of free election; and (5) The is open recruitment to fill critical political positions in the state administrative process. ${ }^{11}$ Based on these five essential elements, the element closely related to the phrase "democratically" in the context of regional head elections through independent and political participation. Both can only be found in the mechanism of direct regional head elections.

\section{INCONSISTENT CONSTITUTIONAL COURT'S DECISION: FROM JUDICIAL ACTIVISM TO JUDICIAL RESTRAINT}

Inconsistency is an attitude or establishment that is disobedient to the principle, likes to change or has parts that are incompatible and contradictory. If this attitude is found in the decisions of the Constitutional Court, then the compliance of the Constitutional Court concerning the principle of legal certainty can be questioned. In the Decision of the Constitutional Court No. 072-073/PUU-II/2004 concerning the petition for testing of the Law No. 32 of 2004 on Regional Government, argues as follows:

As a consequence, disputes regarding election results, according to the applicants, must be decided by the Constitutional Court. Regarding the petition of the applicants to declare Article 106 paragraphs (1) to (7) as opposed to the 1945 Constitution, the Court is of the opinions the legislator can ensure direct election as an extension of the understanding of the Election referred to in Article 22E of the 1945 Constitution. Thus, disputes regarding the results are part of the Constitutional Court's authority with the provisions of the Article 24C paragraph (1) of the 1945 Constitution. However, the legislators can also determine that the direct local election is not an election in the formal sense referred to in Article 22E of the 1945 Constitution so that the outcome of the dispute is determined in addition to the Supreme Court's authority. ${ }^{12}$

11 Zainal Arifin Hoesein, Regional Head Election in the Transition of Democracy, Journal of the Constitution, Volume 7, Number 6, December 2010 at 2.

12 Constitutional Court of the Republic of Indonesia, supra note 4. 
Based on the arguments in the decision, it asserts that the Constitutional Court provides an opportunity for the possibility of regional head elections to be part of Article 22E of the 1945 Constitution or not part of the article. As a result, the authority to adjudicate and decide on the problems of regional head elections is part of the power of the Constitutional Court, and that is valid as long as the legislature makes it that way. Then, on April 28, 2008, Regulation No. 12 of 2008 was promulgated on the Second Amendment to Law No. 32 of 2004 on Regional Government. Article 56 paragraph (1) regulation No. 12 of 2008 on Regional Government ${ }^{13}$ states that regional head elections are held directly like the election of president and vice president. ${ }^{14}$

In addition, Article 236C of Regulation No. 12 of 2008 provides a legal basis as a legality that the Constitutional Court has the authority to decide on issues of regional head elections so that the transfer of settlement of disputes over the results of regional head elections is transferred from the Supreme Court to the Constitutional Court. This means that from the description, it is reasonable if the Constitutional Court has the authority to handle disputes over regional elections because they are under existing legal regulations.

But, the decision No. 97/PUU-XI/2013, in the case of reviewing Law No. 12 of 2008 states that Article 236C does not have legal force binding and and it contradicts to the 1945 Constitution. In particular, it deals with the transfer of authority to settle disputes over the results of regional elections from the Supreme Court to the Constitutional Court. The Constitutional Court in the ruling stated that he was no longer authorized to try and decide on disputes over the results of regional head elections. ${ }^{15}$

The Constitutional Court in the Decision of the Constitutional Court No. 072073/PUU-II/2004 states:

Based on the provisions of Article 24C paragraph (1) of the 1945 Constitution and reaffirmed in Article 10 paragraph (1) letter a of Law No. 24 of 2003 on the Constitutional Court, and Article 50 of Law No. 24 of 2003 that the law that can be petitioned is a law promulgated after the first amendment to the 1945 Constitution on October 10, 1999. While Law on Regional Government was promulgated on October 15, 2004. Thus, the Constitutional Court has the authority to examine, hear, and decide on disputes over regional elections. ${ }^{16}$

However, Decision No. 97/PUU-XI/2013 states that it is no longer authorized to examine, hear, and decide on disputes over regional head elections with legal considerations stating:

The Constitutional Court to safeguard the constitutional system concerning relations between the state institutions of the court must use a rigid approach. Insofar, as the 1945 Constitution regulates the attributive authority of each of these institutions, it is under

13 Article 56 of Law No. 12 of 2008 on Regional Government states: Regional heads and deputy regional heads are elected in one pair of candidates who are carried out democratically based on the principle of direct, general, free, confidential, honest and fair.

14 Zainal Arifin Hoesein, supra note 11.

15 Constitutional Court of the Republic of Indonesia, Decision No. 97/PUU-XI/2013 at 63.

16 Constitutional Court of the Republic of Indonesia, supra note 4 at 103. 
the provisions of the constitution. With the aim of avoiding excessive authority, because if the Constitutional Court does not limit itself to rigid interpretation, it will be very prone to chaos and which indirectly the legislature will be allowed to take on the role of forming the Law Basics of 1945. Otherwise, the Constitutional Court which took over the function of forming the 1945 Constitution to change through its decisions. ${ }^{17}$

As the guardian and the sole interpreter of the constitution, inconsistent decisions of the Constitutional Court should be avoided. In particular, it deals with the power in resolving disputes over the results of regional elections that discuss the norm with the same spirit about regional head elections. The attitude of the judge becomes a significant focus to determine the direction of the judge's decision. This phenomenon is considered as a different way of approaching the attitude of constitutional judges in considering at constitutional issues in the process of testing the law, whether the judge will curb himself or open himself to see other aspects before deciding a case. The attitude of the judge in question is judicial restraint or judicial restrictions and judicial activism or judicial activism. The judicial restraint approach, viz. the court or the judge refrain from making decisions so that they do not include in the domain of the legislative and executive bodies. This theory was introduced by James B. Thayer in his article "The Origin and Scope of the American Doctrine of Constitutional Law" (1893). ${ }^{18}$

Robert Posner provides a clear understanding of judicial restraint. According to Robert Posner, judicial restraint is an attempt by a judge or court to limit themselves within the framework of the principle of separation of powers. ${ }^{19}$ Judicial restraint is a form of court action or a judge whether issue a verdict which may destroy another institution's order. This is also applied by considering this action may exceed the authority that should have been regulated by law. It means that the court or judge can only make decisions that are limited under the law. Invite who has arranged it.

When connected with the judicial process related to judicial review conducted by the Constitutional Court, the authors argue that judicial restraint is a form restraint of the Constitutional Court judge to interpret the 1945 Constitution in order to escort the constitution. Furthermore, judicial restraint has limitations in dealing with constitutional cases, are as follows: ${ }^{20}$

1. Constitutional Limitation. It is a restriction based on the authority granted by regulation on certain institutions, for example, the authority of the Constitutional Court has limited authority stipulated in Article 24C of 1945 Constitution.

2. Policy Limitation. This concept was coined by Justice Brandels in 1936 in the Ashwander V. Tennessee Valey Authority, also known as Aswander Rules.

17 Constitutional Court of the Republic of Indonesia, supra note 15 at 58.

18 Pan Mohamad Faiz, Judicial Restraint vs. Judicial Activism, Magazine Constitution Opinion, No. 130, December 2017 at 8 .

19 Separation of Powers consists of three subdivision authorities are Executive Authority as organizer Government function, Legislative authority as the executor of establishing a law, and judicial power as executors of the features of judicial power. Wicaksana Dramanda, Initiating Application Judicial Restraint in Constitutional Court, Constitution Journal, Volume II, No. 4, December 2014 at 620.

20 Ibid at 621-623. 
This principle leads to the commitment of the court and the judge to refrain or self-restraint in his authority to discuss and decide on the dispute over regulation testing. These Ashwander Rules have seven principles are: ${ }^{21}$

a. Court must avoid giving decisions regarding constitutional issues that arise without any disputes;

b. The court will not decide on an inherent problem until it is decided;

c. The court will always assume that all regulations are constitutional, and impose on the parties whos litigate to prove otherwise;

d. The court will not formulate a decision on a legal issue that exceeds the required needs as described in the trial as far as possible to avoid the formation of new norms;

e. The court will not accept requests that are constitutional questions or cases that have intense political issues if the matter can be resolved through other legal mechanisms;

f. The court will not accept applications for judicial review submitted by those who cannot prove the loss they experienced due to the enactment of the law; and

g. The court will not consider the constitutional review of a regulation that is requested for the benefit of appealing to the applicant.

These seven principles constitute a series of forms of restraints from the courts and judges in order not to issue decisions that are contrary to the seven principles. The meaning is the judges still adheres to the constitution and is obedient to the constitution and limits himself with limited authority as regulated by regulation.

3. Restrictions Based on Doctrine Limitation. Doctrine Limitation is a limitation of courts and judges to hold back against certain doctrines. This principle is a part of the application of prudence of judges in deciding cases of regulation testing.

In addition to judicial restraint, there are different dimensions of judicial activism or what is called judicial activism. This concept was first proposed by Arthur Schlesinger in January 1947 in Fortune magazine. This concept is very closely related to the context of judges making legal rules in the trial process or referred to as judges making law. ${ }^{22}$ Brian Galligan defines judicial activism as the control or influence of judicial institutions on political and administrative institutions. The meaning is the court interferes in matters that are not part of its authority, which is included in the judicial and executive domain. ${ }^{23}$ Article written by Frank B. Cross and Stefanie A. Lindquist about the scientific study of judicial activism revealed that discussions about judicial activism had only focused on the implementation of judicial review and had failed to

21 Ibid at 622

22 Pan Mohamad Faiz, Dimension of Judicial Activism in Decision of the Constitutional Court, Jurnal Konstitusi, Volume 13, Number 2, June 2016 at 408.

23 Pan Mohamad Faiz, Judicial Restraint vs. Judicial Activism, supra note 18. 
take into account other actions called activism. Judicial activism should be defined in 6 (six) dimensions as follows: ${ }^{24}$

1. Majoritarianism, the degree to which policies adopted through democratic processes are judicially negated

2. Interpretive stability, the degree to which earlier court decisions, doctrines, or interpretations are altered

3. Interpretive fidelity, the degree to which constitutional provisions are interpreted contrary to the clear intentions of their drafters or the clear implications of the language used

4. Substance/Democratic process distinction, the degree to which judicial decisions make substantive policy rather than affect the preservation of democratic processes

5. Specificity of policy, the degree to which judicial decisions establishes policy itself as opposed to leaving discretion to other [governmental actors], and

6. Availability of an alternate policymaker, the degree to which judicial decisions supersedes serious consideration of the same problem by other [political actors]

Not a bit then there are the views that provide negative and positive impression of the impact of the implementation of judicial activism. William P. Marshall outlines the threat to the function of democracy that comes from the judicial activism process, which is called the seven sins of judicial activism: ${ }^{25}$

1. Counter - Majoritarian Activism: reluctance from the court to submit the power of other democratically elected branches of power;

2. Non-Orgiginalist Activism: failure of the court to provide the original ideas when deciding cases;

3. Precedential Activism: failure of the court to submit to previous court decision/judicial precedent;

4. Jurisdictional Activism: failure of the court to comply with the boundaries of its jurisdiction;

5. Judicial Creativity: the creation of new theories and rights in constitutional doctrine;

6. Remedial Activism: the use of court power to force ongoing affirmative obligations against the government or to take over duties from government institutions under the supervision of the court; and

7. Partisan Activism: use of court power to achieve partisan goals.

On the other hand, other critics argue that the court exceeds its authority in carrying out their duties, viz. as a body that maintains the application of law under the constitution, Article 24 paragraph (1) and (2) on the power of the judiciary in organizing a trial for creating justice and maintaining it. In contravention of

24 Frank B. Cross and Stefanie A. Lindquist, The Scientific Study of Judicial Activism, 6/15/2007 at 1762.

25 Pan Mohamad Faiz, supra note 22 at 409. 
fundamental rules, for example, courts and judges should carry out regulated functions and authorities established by the legislator. But, in this concept, the court is seen as overly interventionist in policy that have been made by legislative and executive institutions in the political, social, and economic fields.

Positive views emerged from human rights activists and pro-democracy activists, who viewed judicial activism as a process of adaptation from the law to adjust to existing social changes. This process is proceeded by redeveloping the values and basic principles of the constitution and existing court decisions to represent constitutional values that are not clearly stated in the law. The problem is that it is necessary to apply then a measure that can limit the extent to which this judicial review can be applied in a country because of course, different opinions will emerge among the wider community to accept and reject this concept. It is possible for judicial activism at any time to have legitimacy or even to lose the legitimacy of the people who view the law as just a written rule of law. According to Christopher G. Buck, in general, judicial activism must be based on legal principles and cannot be separated only by court discretion. ${ }^{26}$ That meaning is, the use of judicial activism is not arbitrary interpreted because there will always be a legal mechanism that should include into consideration.

Based on this description, the author will describe the attitude of constitutional justices in Decision No. 072-073/PUU-II/2004 and No. 97/PUU-XI/2013. First, in Decision No. 072-073/PUU-II/2004, the Constitutional Court places itself in judicial activism. The following is the reason for the authors concluding that the judge's decision in case 072-073/PUU-II/2004 is the judge's attitude as a form of judicial activism:

a. On Decision No. 072-073/PUU-II/2004, as previously described, it is inevitable that in the legal consideration, constitutional judges argue:

By considering constitutional basis, the legislator can ensure that the direct local election is an extension of the understanding of the Election referred to in Article 22E of the 1945 Constitution. Thus, the dispute regarding the results becomes part of the Constitutional Court's authority with the provisions of Article 24C paragraph (1) of the 1945 Constitution. This Article states that the Constitutional Court has to decide upon disputes over the results of general elections. The legislator can also determine that the direct local election is not an election in the formal sense referred to in Article 22E of the 1945 Constitution. Then, the outcome of the dispute is included in addition to the power of the Supreme Court in Article $24 \mathrm{~A}$ paragraph (1) of the 1945 Constitution. This article state that the Supreme Court has the authority to decide at the cassation level, examine the statutory provisions under the law against the law and has other powers granted by law. ${ }^{27}$

This fact asserts that there is an open or public legal policy that is permitted by the Constitutional Court. The Court looks forward or

26 Ibid at 411.

27 Constitutional Court of the Republic of Indonesia, supra note 4 at 114 . 
futuristic related to the politics of law formation, whether democratic elections can be equated with the elections referred to in Article 22E of the 1945 Constitution and submitted to the legislators to determine them. It conforms with Brian Galligan's argument that judicial activism is the control or influence of judicial institutions on political and administrative institutions $^{28}$. It means that the Constitutional Court as one of the judicial institutions indirectly influences the legislature to form legal politics through the relevant decision.

b. This opinion is also supported by the opinion of Frank B. Cross and Stefanie A. Lindquist. In their article on the scientific study of judicial activism, judicial activism can be defined as "availability of an alternate policymaker, serious judgment of the same serious consideration of the same problems by other [political actors]..$^{29}$ So it can be interpreted that the casu quo court ruling of the Constitutional Court has an influence on the legislature. This influence is materialized by providing alternative policies to the legislators to determine whether the term democratically elected local elections can be understood as a general election under Article 22E of the 1945 Constitution.

The Constitutional Court in Decision No. 97/PUU-XI/2013 applied judicial restraint. The following reasons by authors in case $97 / \mathrm{PUU}-\mathrm{XI} / 2013$ judges are bound to judicial restraint. The perspective of judicial restraint in the decision of the Constitutional Court Number 97/PUU-XI/2013 is confirmed in the Court's judgment stating:

The Constitutional Court in order to preserve the constitutional system concerning relations between the state institutions of the court must use a rigid approach. This rigid approach is applied by rejecting other perspectives. Insofar, as the 1945 Constitution regulates, the attributive authority of each of these institutions is under the constitution. This effort aims to avoid excessive authority, because if the Constitutional Court does not limit itself to rigid interpretation, this institution will take roles of forming law and regulations. ${ }^{30}$

Based on these considerations, the Court limits itself to giving an interpretation of the constitution to avoid any chaos between judicial and legislative institutions by limiting authority based on the 1945 Constitution of the Republic of Indonesia. As Robert Posner argues, judicial restraint is a judge's attempt to detain self-based on the principle of separation of powers. In addition, there is a need to apply the indicator of constitutional limitation to the attitude of the Constitutional Court as a judicial restraint. This means that the Court limits its power based on the law that grants such authority. For example, this is to restrict its power based on Article 24C of the 1945 Constitution.

28 Pan Mohamad Faiz, supra note 22.

29 Frank B. Cross and Stefanie A. Lindquist, supra note 24.

30 Constitutional Court of the Republic of Indonesia supra note 15 at 58. 


\section{LEGAL UNCERTAINTY AFTER THE DECISION OF THE CONSTITUTIONAL COURT}

This section will discuss the impact of legal uncertainty arising from inconsistencies between the Constitutional Court Decision No. 072-073/PUU-II/2004 and No. 097/PUU-XI/2013. Before reviewing the impact of legal uncertainty because of the inconsistency of the Constitutional Court, the author will discuss the essence of legal certainty. Legal certainty is difficult to be separated from justice and legal certainty. The inseparability of justice and legal certainty refers to Gustav Radbruch's thesis that something created must have ideals and goals, as well as the regulation purpose of the law must contain certainty, justice and expediency. ${ }^{31}$

Dimensions of legal certainty is often associated with the flow of legal positivism. According to H.L.A Hart, the essence of legal positivism can be describe as follows: (a) law is a commandment; (b) there is no wholeness to connect the law with morality, the law as enacted, determined, positive, must always be separated from law that should be created, which is desirable; (c) analysis or study the meaning of legal concepts is a critical study, review or study must be distinguished from historical studies, sociological studies, and critical judgments of moral sense, social goals, and social function; (d) he legal system is a logical closed system, which is the right decision that can be deduced logically from the rules that already exist; and (e) moral condemnation can no longer be enforced, and it must be by way of rational argument or proof by evidence. $^{32}$

Based on the essence of the legal positivism, Hart separated the law from moral, social functions, and social goals. It means, to achieve legal certainty, the law must apply under the text, as stipulated, ratified, and promulgated by the government or the authorities. If associated with Jan Michel Otto's opinion, legal certainty can be defined as the possibility in certain situations: ${ }^{33}$

1. Clear legal rules are available, consistent and easily accessible, issued by and recognized because of state power;

2. The authorities (government) apply these legal rules consistently and are also submissive and obedient to them;

3. Residents in principles adjust their behavior to these rules;

4. The judges (Court) are independent and impartial tribunal applying legal rules consistently as they settle legal disputes; and

5. The court decision concretely implemented.

Based on the opinion of H.L.A Hart and Jan Michel Otto, the authors argue that legal certainty is the achievement of the application of codified laws. For example, in the judicial process, when a judge applies the law under the law in force at that time. As already stated that in addition to legal certainty, there is also justice and benefit of the

31 Fence M. Wantu, Antinomy in Law Enforcement by Judges, Legal Pulpitum, Volume 19, Number 3, October 2007 at 388.

32 Teguh Prasetyo and Abdul Halim Barkatullah, Law and Philosophy in Law, Yogyakarta: Student Library, 2011 at 97.

33 Fence M. Wantu, supra note 31 at 393. 
law, which is an inseparable part of the nature of the law itself. If the dimensions of legal certainty are confronted with the inconsistency of decisions due to a shift in the judge's perspective, then there are at least 3 (three) important criticisms that can be addressed to the Constitutional Court, namely:

1. Constitutional interpretation by the Constitutional Court is considered not final. In the context of the inconsistency of the Constitutional Court Decision No. 072-073/PUU-II/2004 and No. 097/PUU-XI/2013 which resulted in legal certainty, there was a weakening function of the Constitutional Court as the final interpreter (the final interpreter of the constitution). As a final interpreter, the Constitutional Court's ruling should have a value of predictability when the same substance in two different laws tested in the Constitutional Court. Ideally, the Court's Decision is consistent between previous and later decisions. This argument conforms with H. Hart's opinion about the essence of legal positivism, that law is a logical system. It means that the law in the form of a court decision is expected to be predictable with reason or deduced by drawing a conclusion that the law in adjudicating similar cases/disputes can produce consistent decisions.

2. Disillusionment with the Constitutional Court. The Constitutional Court, as the interpreter and guardian of the constitution, must be an institution capable of maintaining its authority so that the public does not have a bad impression on the performance of the Constitutional Court. The complexity of the problems in the legal system, particularly the inconsistency of court decisions, will lead to the tendency of disrespect and distrust of the judiciary (judicial organs), especially in this context the Constitutional Court. The importance of consistency in law enforcement was also expressed by Jan Michiel Otto, who stated that judges (judiciary) are independent in resolving legal disputes and applying the legal rules consistently, so between law and law enforcement can be aligned to create a good law enforcement system. When law enforcement is consistent, the legal culture will be formed through public awareness and respect for the regulation and law enforcement officers. The problem is, how can community respect the law is the judiciary is not consistent in interpreting the law?

3. The inconsistency Court's Decision raises a legal vacuum. The legal vacuum is that there are no rules or laws then regulate the authority of institution which is authorized to hear the case disputes the result of the local elections. Because if the Constitutional Court Decision No. 072-073/PUUII/2004 and the Constitutional Court's Decision 97PUU-II/2013 Decision decide consistently, then the logical consequence is the dispute over the dispute results of the regional head elections becomes the authority of Constitutional Court. 
The Constitutional Court since 2013 still tried to dispute over the result of the election of the regional heads and deputy regional head of the area although on the other hand there are no rules that govern over these powers. For example in Decision No. 54/PHP.BUP-XI/2017 in the case of dispute over the result of elections of regents and deputy regents of Intan Jaya Regency, Papua Province proposed by Natalis Tabuni and Yann Robert Kobogoyauw ${ }^{34}$ and Decision No. 107/PHP.KOT-XI/2016 for cases of disputes over the results of the election of mayor and deputy mayor submitted by $\mathrm{H}$. Arsid and Elvier Ariadiannie Soedarto Putri. ${ }^{35}$ In both example the decision can be seen that the Constitutional Court examines, hears and decides the dispute based on the uncertainty of a clear legal basis, while Article 157 paragraph (1) of Law No. 8/2015 test cases disputes the result of the local elections is carried out by the court specifically established by the national government, which until now the special court has not yet been formed. Besides the legal uncertainty that governs the authority to examine disputes over the results of regional elections, the author considers it necessary to give appreciation to the Constitutional Court for maintaining and ensuring that the constitutional system continues to run well, especially in the context of material testing if there is a post-conflict local election.

\section{CONCLUSION}

The analysis in this article shows that there is an inconsistency in decisions of the Constitutional Court No. 072/073/PUU-II/2004 and No. 97/PUU-XI/2013 on the authority of dispute over the election of regional heads and deputy regional heads. This inconsistency occurred because of the shift in the perspective of judges from judicial activism to judicial restraint. Shifting perspective that impact on the discrepancies of the Constitutional Court has the potential to create legal uncertainty. Therefore, the Constitutional Court, as the sole interpreter of the constitution, must interpret the values contained in the 1945 Constitution consistently, to avoid changing interpretations of the constitution. Although there was a shift in the perspective of the judges in the interpretation, the Constitutional Court should avoid a legal vacuum. In the context, a legal vacuum is defined as the absence of rules or laws that provides legality, which refers to which agency the authority to decide disputes over the results of local elections was given.

Constitutional Court of the Republic of Indonesia, Decision No. 54/PHP.BUP-XV/2017.

35 Constitutional Court of the Republic of Indonesia, Decision No. 107/PHP.KOT-XIV/2016

36 Article 157 paragraph (1) of Law No. 8 of 2015 on the Amendment to Law No. 1 of 2015 on the Determination of Government Regulations in lieu of Law No. 1 Year 2014 on Election of Governors, Regents and Mayors to Become Acts. This article outlines as follow: "Cases of Election result disputes are examined and tried by special judicial bodies." 


\section{REFERENCES}

Comprehensive Script Changes of the Constitution of Republic Indonesia 1945, Book V general election (Jakarta: General Secretariat and Constitutional Courtesy, 2010).

General Secretariat and Constitutional Courtesy, Constitutional Court Procedural Law (Jakarta, General Secretariat and Constitutional Courtesy, 2010).

Maggalatung, A Salman. "Relations between Facts, Norms, and Legal Doctrines in Judicial Judgment Considerations "(2014) Legal Journal, Volume II, Number 2.

Cross, Frank B. and Stefanie A. Lindquist. "The Scientific Study of Judicial Activism (2007)

Wantu, Fence M. "Antinomy in Law Enforcement by Judges" (2007) Legal Pulpit, Volume 19, Number 3.

Faiz, Pan Mohamad. "Judicial Restraint vs. Judicial Activism" (2017) Opinion of Constitutional Magazine, Number 130.

Faiz, Pan Mohamad. "Dimensions of Judicial Activism in Constitutional Court Decisions" (2016) Journal of the Constitution, Volume 13, Number 2.

Rusli. "Constitutional Review of the Authority of the Constitutional Court in Deciding Election Disputes" (2015) e-Journal Catalogis Volume 3, Number 12.

Sulardi and Yohana Puspitasari Wardoyo. "Legal Certainty, Use and Justice for Child Criminal Cases" (2015) Judicial Journal, Volume 8, Number 3.

Setiawan, Sigit. "Inconsistency of Constitutional Court Decision Regarding Authority to Trial Dispute over Regional Head Elections" (2016) Thesis, Muhammadiyah Surakarta Faculty of Law.

Dramanda, Wicaksana. "Initiating the Implementation of Judicial Restraint in the Constitutional Court" (2014) Journal of the Constitution, Volume 11, Number 4.

Hoesein, Zainal Arifin Election. "Regional Head in the Transition of Democracy" (2010) Journal of the Constitution, Volume 7, Number 6. 
336 | Inconsistent Constitutional Court Decisions Resulting in Uncertainty in Legal Dispute ...

This page is intentionally left blank 